\title{
CORPORATE GOVERNANCE DAN KARATERISTIK PERUSAHAAN TERHADAP MANAJEMEN RESIKO PADA PERUSAHAAN KOMPAS 100
}

\section{CORPORATE GOVERNANCE AND COMPANY'S CHARATERISTIC AGAINST RISK MANAGEMENT IN KOMPAS 100}

\author{
Dedi Putra1) , Nur Istiqomah2) \\ Institute Informatika dan Bisnis Darmajaya, Lampung \\ Email : dedi.putra@darmajaya.ac.id, nuristiqomah@gmail.co.id
}

\begin{abstract}
ABSTARAK
Penelitian ini bertujuan untuk membuktikan secara empiris ukuran komite audit, kepemilikan institusional, ukuran perusahaan, profitabilitas dan leverage berpengaruh terhadap manajemen resiko perusahaan kompas 100 . Populasi untuk penelitian ini menggunakan data-data keuangan perusahaan yang terdaftar di kompas 100 pada tahun 2016-2018. Pemilihan sampel dilakukan dengan metode puposive sampling dengan menetapkan kriteria sampel sebanyak 144 sampel selama 3 tahun observasi penelitian. Metode analisis menggunakan kualitatif dengan alat analisis spss ver.23. hasil penelitian yaitu ukuran komite audit, kepemilikan institusional, profitabilitas dan leverage tidak berpengaruh terhadap manajemen resiko sedangkan ukuran perusahaan berpengaruh terhadap manajemen resiko.
\end{abstract}

Kata Kunci : Corporate Governance, Karakteristik perusahaan dan Manajemen Resiko.

\begin{abstract}
The research aims to prove empirically the size of the audit Committee, institutional ownership, company size, profitability and leverage affects on the company's risk management Compass 100. The population for this study used the company's financial data listed on the Compass 100 in 2016-2018. The sample selection is done by the Puposive sampling method by setting sample criteria as much as 144 samples during 3 years of research observation. Method of analysis using qualitative with analysis tool SPSS ver. 23. Research results are the size of the audit Committee, institutional ownership, profitability and leverage has no effect on risk management while the size of the company affects the risk management.
\end{abstract}

Keywords: Corporate Governance, company characteristics and risk management. 


\section{PENDAHULUAN}

Perusahaan dalam setiap aktivitasnya akan selalu dihadapkan dengan risiko. Suatu pernyataan yang mengatakan "high risk bring about high return" artinya jika ingin mendapatkan hasil yang besar, maka perusahaan juga akan mendapatkan risiko yang lebih besar pula (Anisa, 2012), Semakin meningkatnya level perusahaan akan diikuti pula dengan meningkatnya level risiko. Persaingan dunia bisnis yang sangat ketat mendorong kebutuhan perusahaan untuk mengelola risiko secara efektif untuk mengurangi kerugian yang dapat terjadi pada perusahaan.

Manajemen risiko adalah serangkaian metodologi dan prosedur yang digunakan untuk mengidentifikasi, mengukur, dan mengendalikan risiko yang timbul dari seluruh kegiatan usaha, baik risiko kredit, risiko operasional, maupun risiko - risiko lainnya dalam upaya memaksimalkan nilai perusahaan (Rustam, 2017: 12). Proses dalam metodologi tersebut bertujuan untuk mengelola risiko yang diprediksi akan terjadi sehingga perusahaan dapat menghadapi dan menghindari suatu risiko. Manajemen risiko dapat meminimalisir dan mengatasi dampak buruk atau kerugian bagi perusahaan akibat risiko. Manajemen risiko yang berjalan dengan baik dapat memberikan manfaat yang baik untuk perusahaan, seperti efektivitas organisasi berjalan dengan efisien, pelaporan risiko menjadi lebih transparansi, dan kinerja bisnis semakin meningkat. Penerapan manajemen risiko yang berhasil dapat mendorong pengungkapan yang lebih transparansi sehingga dapat menjadi dasar bagi para principal dan agent untuk mengambil keputusan dengan tepat.Peraturan Otoritas Jasa Keuangan Nomor 29/POJK.04/2016 tentang Laporan Tahunan Emiten atau Perusahaan Publik menjelaskan bahwa perusahaan go publik wajib menyampaikan informasi mengenai kegiatan perusahaan dalam bentuk laporan tahunan (annual report). Pengungkapan manajemen risiko dapat dilakukan melalui laporan tahunan perusahaan. Perusahaan harus transparans dalam melakukan pengungkapan informasi risiko kepada para seluruh pemakai laporan tahunan perusahaan. artinya informasi yang disampaikan bukan hanya yang bersifat positif saja namun termasuk informasi yang bersifat negatif terutama yang terkait dengan aspek manajemen risiko dengan harapan asimetri informasi dapat dikurangi.

Pengungkapan risiko merupakan salah satu strategi untuk menjaga hubungan manajemen perusahaan dengan para stakeholder atau principal. Tidak adanya pengungkapan risiko menyebabkan timbulnya asimetri informasi antara manajemen dan pemilik sehingga akan memicu munculnya keputusan yang akan diambil menjadi tidak tepat bahkan salah. Dengan adanya pengungkapan risiko yang dilakukan oleh perusahaan, maka hal tersebut dapat membantu pemilik dan manajemen untuk mengambil keputusan secara tepat dan cermat. Dengan adanya pengungkapan manajemen risiko yang dilakukan oleh perusahaan akan memberikan informasi kepada pemilik dan manajemen dalam pengambilan keputusan dan mengurangi adanya asimetri informasi serta dapat meningkatkan kualitas laporan keuangan perusahaan.

Kasus Dikutip dari Kontan.co.id lembaga akuntan publik Ernst \& Young (EY) mengeluarkan audit soal dugaan pelanggaran yang dilakukan oleh manajemen lama PT Tiga Pilar Sejahtera Food Tbk (AISA). Terdapat overstatement sebesar Rp. 4 triliun pada akun piutang usaha, persediaan, dan aset tetap Grup AISA dan sebesar Rp. 662 miliar pada penjualan serta Rp. 329 miliar pada EBITDA Entitas Food. Terdapat dugaan aliran dana sebesar Rp. 1,78 triliun dengan berbagai skema Grup AISA Kepada pihak - pihak yang diduga terafiliasi dengan manajemen lama antara lain dengan menggunakan pencairan pinjaman AISA dari beberapa bank dan pencairan deposito berjangka. Terkait hubungan transaksi dengan pihak terafiliasi tidak ditemukan pengungkapan (disclosure) secara memadai kepada para pemangku kepentingan (stakeholders) yang relevan. Akibat dari kurangnya pengungkapan informasi menjadikan tingkat kepercayaan para investor dan pengguna laporan keuangan PT Tiga Pilar Sejahtera Food Tbk 
terhadap pengungkapan laporan keuangan menjadi menurun yang bisa disebut dengan risiko reputasi. Tingkat risiko likuiditas dimana risiko yang muncul akibat ketidakmampuan perusahaan untuk memenuhi kewajibannya juga terjadi pada PT Tiga Pilar Sejahtera Food Tbk akibat menunda pembayaran surat hutang hingga krediturnya mengajukan Penundaan Kewajiban Pembayaran (PKPU) ke pengadilan dan berdampak buruk pada harga saham perusahaan menjadi turun sehingga para investor mengalami kerugian akibat mengambil keputusan yang tidak tepat karena kurangnya pengungkapan informasi mengenai manajemen risiko.

Dari peristiwa tersebut dapat disimpulkan bahwa manajemen risiko pada perusahaan tersebut tidak dikelola dengan baik. Risiko yang tidak dapat dikelola dengan baik melalui manajemen risiko dapat menyebabkan kerugian pada suatu perusahaan. Pengungkapan informasi yang berpengaruh dalam pengambilan keputusan adalah pengungkapan manajemen risiko maka penting bagi perusahaan untuk melakukan pengungkapan manajemen risiko secara transparan, luas dan detail. Kurangnya pengungkapan manajemen risiko di indonesia dan tingginya permintaan para investor terhadap pengungkapan manajemen risiko serta beberapa regulasi yang menuntut perusahaan dalam pengungkapan manajemen risiko mencerminkan betapa pentingnya pengungkapan manajemen risiko yang mendasari penelitian ini dilakukan. Pengungkapan manajemen risiko yang akan diteliti adalah pengungkapan manajemen risiko pada laporan keuangan tahunan.

\section{LANDASAN TEORI}

\section{Mekanisme Corporate Governance}

Good Corporate Governance (Effendi, 2009) adalah suatu sistem pengendalian internal perusahaan yang memiliki tujuan utama untuk mengelola risiko yang bersifat signifikan guna memenuhi tujuan bisnisnya melalui pengamanan aset perusahaan dan meningkatkan nilai investasi pemegang perusahaan dalam jangka panjang. Good Corporate Governace adalah suatu tata kelola sektor perbankan yang menerapkan prinsipprinsip keterbukaan (transparancy), akuntabilitas (accountability), pertanggungjawaban (responsibility), independensi (independency), dan kewajaran (fairness). (Peraturan Bank Indonesia No. 8/4/PBI/2006 tentang Pelaksanaan Good Corporate Governance pada Bank Umum).

\section{Karakteristik Perusahaan}

Kinerja adalah suatu gambaran dari pencapaian pelaksanaan suatu kegiatan atau proses kebijakan dalam mewujudkan sasaran, tujuan, visi, misi dalam sebuah organisasi. Pelaporan kinerja merupakan bentuk kewajiban untuk mempresentasikan dan melaporkan kinerja semua aktifitas dan semua sumber daya yang perlu dipertanggungjawabkan. Kinerja perusahaan ditentukan sejauh mana keseriusan dalam menerapkan Good Corporate Governance. Perusahaan yang telah terdaftar namanya dalam skor peningkatan corporate governance yang dilakukan oleh IICG telah menerapkan good corporate governance dengan baik dan secara langsung menaikkan nilai perusahaan.

\section{Manajemen Resiko}

Risk Management Lingkungan internal dan eksternal perbankan yang berkembang pesat disertai dengan risiko kegiatan usaha bank yang semakin kompleks, menuntut Bank untuk menerapkan manajemen risiko yang memadai dan dilaksanakan secara disiplin. Penerapan manajemen risiko pada perbankan sangat penting dalam menciptakan industri perbankan yang sehat dan terintegrasi, agar bisnis Bank dijalankan dalam koridor risiko yang tetap terkendali. 
Penerapan manajemen risiko yang tertib pada setiap Bank pada dasarnya akan menciptakan industri perbankan yang semakin sehat (IBI, 2015, p. 4).

\section{Mekanisme Corporate Governance dan Manajemen Resiko}

Semakin besar jumlah anggota Komite Audit dalam perusahaan maka dapat mempengaruhi luas pengungkapan risiko dalam laporan keuangan tahunan perusahaan. Penelitian yang dilakukan oleh Kencana dan Lastanty (2018) menemukan bahwa tidak terdapat pengaruh antara ukuran Komite Audit terhadap pengungkapan risiko.Namun, penelitian yang dilakukan oleh Syaifurakhman dan Laksito (2016) menemukan bahwa terdapat pengaruh antara ukuran Komite Audit terhadap pengungkapan risiko. Berdasarkan penjelasan diatas, maka dapat diperoleh hipotesis sebagai berikut :

\section{$\mathrm{H}_{1}$ : Ukuran Komite Audit berpengaruh terhadap pengungkapan manajemen risiko}

Teori keagenan memperkirakan bahwa struktur kepemilikan mempengaruhi tingkat pengawasan dalam perusahaan yang berdampak pada tingkat pengungkapan sukarela (Mubarok dan Rohman, 2013). Mangena dan Pike (2005) menemukan pengaruh yang signifikan antara kepemilikan institusional terhadap pengungkapan risiko. Namun, (Mubarok dan Rohman, 2013) menemukan pengaruh yang tidak signifikan antara kepemilikan institusional terhadap pengungkapan risiko.

$\mathrm{H}_{2}$ : Kepemilikan institusional berpengaruh terhadap pengungkapan manajemen risiko

\section{Karakteristik Manajemen dan Manajemen resiko}

Perusahaan besar akan lebih banyak mengungkapkan dibandingkan perusahaan kecil karena dianggap mampu untuk menyediakan informasi tersebut. Perusahaan yang besar menyediakan laporan untuk keperluan internal (agent), dimana informasi tersebut juga digunakan sebagai bahan untuk memenuhi kebutuhan informasi kepada pihak eksternal (principa), sehingga tidak perlu mengeluarkan biaya tambahan. Pengungkapan informasi yang luas pada perusahaan besar merupakan upaya untuk mengurangi biaya keagenan (Anisa dan Prastiwi, 2012).

\section{$\mathrm{H}_{3}$ : Ukuran perusahaan berpengaruh terhadap pengungkapan manajemen risiko}

Tingginya tingkat leverage suatu perusahaan maka akan menentukan luasnya pengungkapan risiko yang harus dilakukan oleh perusahaan. Hal tersebut terjadi karena semakin tingginya tingkat utang suatu perusahaan maka akan meningkat pula risiko pada perusahaan tersebut. Sehingga pihak kreditur selaku stakeholder membutuhkan transparansi pelaporan keuangan dan pertanggungjawaban atas penggunaan dana yang telah dipinjamkan sebagai tolak ukur dalam pengembalian hutang (Jannah, 2016).

\section{$\mathrm{H}_{4}$ : Leverage berpengaruh terhadap pengungkapan manajemen risiko}

Harahap (2016:304) Profitabilitas merupakan tingkat kemampuan perusahaan dalam memperoleh laba melalui semua kemampuan, dan sumber yang ada seperti kegitan penjualan. Tingginya profitabilitas suatu perusahaan dapat menimbulkan ketertarikan investor untuk membeli saham atau berinvestasi di suatu perusahaan. Semakin besar profitabilitas yang dihasilkan perusahaan, maka akan semakin luas pengungkapan risiko yang harus dilakukan karena menunjukkan kepada Principal mengenai kemampuan perusahaan dalam mengefisienkan penggunaan modal di dalam perusahaannya.

\section{$\mathrm{H}_{5}$ : Profitabilitas berpengaruh terhadap pengungkapan manajemen risiko}




\section{METODELOGI PENELITIAN}

Desain penelitian adalah rencana atau rancangan yang dibuat oleh seorang peneliti, sebagai ancangan penelitian yang akan dilaksanakan, yang berisi mengenai satu penelitian yang akan dilakukan, mendeskripsikan kaitan antar variabel, populasi dan sampel, teknik sampling apa yang dipilih, cara pengumpulan data, metode analisis data yang digunakan, dan lain-lain. Dapat diartikan bahwa desain penelitian ini adalah tahapan yang akan ditempuh oleh peneliti dalam melakukan penelitiannya. Penelitian ini bertujuan untuk membuktikan secara empiris ukuran komite audit, kepemilikan institusional, ukuran perusahaan, profitabilitas dan leverage berpengaruh terhadap manajemen resiko perusahaan kompas 100. Populasi untuk penelitian ini menggunakan data-data keuangan perusahaan yang terdaftar di kompas 100. Pemilihan sampel dilakukan dengan metode purposive sampling dengan menetapkan kriteria sampel. Purposive sampling adalah teknik penentuan sampel dengan penilaian tertentu (Sugiyono, 2014: 81).

Kriteria-kriteria sampel penelitian ini yaitu :

1. Sampel yang dipilih adalah perusahaan yang bergerak di sektor Non-keuangan yang terdapat dalam index Kompas 100.

2. Sampel yang dipilih adalah perusahaan yang termasuk dalam index kompas 100 berturut turut sejak tahun 2016 - 2018 yang terdaftar di BEI.

3. Sampel yang dipilih adalah perusahaan yang mempublikasikan laporan tahunan 2016 2018 secara lengkap.

4. Sampel yang dipilih adalah perusahaan yang mempublikasikan laporan tahunan yang dinyatakan dalam satuan nilai rupiah $(\mathrm{Rp})$

5. Sampel yang dipilih adalah perusahaan yang memiliki data - data lengkap yang terkait dengan variabel penelitian.

Jenis data yang digunakan dalam melakukan penelitian ini adalah data sekunder. Teknik pengumpulan data yang digunakan dalam penelitian ini adalah teknik dokumentasi, yaitu dengan menganalisis data yang diperoleh Annual Report perusahaan kompas 100. Metode analisisa yang digunakan dalam penelitian ini adalah metode analisis kuantitaif. Metode analisis data terdiri dari analisis statistik deskriptif, uji asumsi klasik, uji analisis regresi linear berganda, uji hipotesis, dan uji koefisien determinasi.

\section{HASIL DAN PEMBAHASAN}

Penelitian yang dilakukan ini menggunakan metode deskriptif kuantitatif. Dimana datadata kuantitatif dalam penelitian ini yaitu berupa laporan keuangan tahunan yang telah dilaporkan pajaknya setiap tahun. Metode penelitian yang dipakai dalam penelitian ini yaitu metode deskriptif kuantitatif. Populasi dalam penelitian ini adalah perusahaan kompas 100 selama tiga tahun dimulai dari tahun 2016 sampai tahun 2018. Selanjutnya untuk teknik pengambilan sampel yang digunakan dalam penelitian ini yaitu purposive sampling, dimana sampel yang akan dijadikan penelitian berasal dari populasi, sampel diambil sesuai dengan kriteria yang telah ditentukan.

\section{Hasil Analisis Uji Asumsi Klasik \\ Hasil Uji Normalitas}

Hasil uji normalitas data dengan menggunakan Kolmogorov - Smirnov menunjukkan bahwa variabel dependen $\mathrm{K}-\mathrm{Z}$ sebesar 0,874 dengan tingkat signifikan sebesar 0,429 sehingga dapat disimpulkan bahwa data dalam model regresi terdistribusi secara normal, dimana nilai 
signifikan diatas $0,05(0,429>0,05)$. Dengan demikian, secara keseluruhan dapat disimpulkan bahwa nilai - nilai observasi data telah terdistribusi normal dan dapat dilanjutkan dengan uji asumsi klasik lainnya.

\section{Hasil Uji Multikolinieritas}

Berdasarkan hasil uji multikolinieritas diketahui bahwa nilai Ukuran Perusahaan (UK) menunjukkan hasil perhitungan tolerance sebesar 0,843 dan nilai VIF sebesar 1,186 , nilai tolerance Leverage (LV) sebesar 0,879 dan nilai VIF sebesar 1,138, nilai tolerance Profitabilitas (PBL) sebesar 0,933 dan nilai nilai VIF sebesar 1,072, nilai tolerance Ukuran Komite Audit (UKA) sebesar 0,951 dan nilai VIF sebesar 1.051, dan nilai tolerance Kepemilikan Institusional (KI) sebesar 0,921 dan nilai VIF sebesar 1,086. Dari hasil diatas diperoleh kesimpulan bahwa seluruh nilai VIF disemua variabel penelitian lebih kecil dari 10 dan nilai tolerance lebih besar dai 0,10. $\mathrm{Hal}$ ini menunjukkan bahwa tidak terdapat korelasi antara variabel bebas atau tidak terjadi masalah multikolinieritas diantara variabel independen dalam model regresi.

\section{Hasil Uji Heteroskedatisitas}

Salah satu cara untuk mendeteksi adannya heteroskedastisitas adalah dengan melihat grafik plot antara nilai pediksi variabel independen (ZPRED) dengan residualnya (SPRESID). Deteksi ada atau tidaknya heteroskedastisitas dapat dilakukan dengan melihat ada tidaknya pola tertentu pada grafik scatterplot antara SPRESID dan ZPRED dimana sumbu $Y$ adalah $Y$ yang telah di prediksi, dan sumbu $X$ adalah residual ( $Y$ prediksi $-Y$ sesungguhnya) yang telah distudentized. Dari gambar 4.1 diatas terlihat titik - titik menyebar secara acak serta tersebar baik diatas maupun dibawah angka 0 pada sumu $Y$, tidak ada pola tertentu yang teratur. Dengan demikian, dapat disimpulkan bahwa tidak terjadi heteroskedastisitas pada model regresi ini.

\section{Hasil Uji Autokorelasi}

Hasil uji ini menunjukkan bahwa nilai DW test sebesar 2,110. Nilai ini dibandingkan dengan nilai tabel menggunakan derajat keyakinan $95 \%$ dan $a=5 \%$ dengan jumlah sampel sebanyak 144 sampel serta jumlah variabel independen sebanyak 5, maka tabel durbin watson akan didapat nilai dU sebesar 1,8000. Dapat disimpulkan nilai dU sebesar 1,8000 lebih kecil dari DW test sebesar 2,110 lebih kecil dari $4-\mathrm{dU}$ atau 2,2. Diperoleh kesimpulan bahwa $\mathrm{dU}<\mathrm{d}<4-$ dU atau $1,8000<2,110<2,2$. Dengan demikian bahwa tidak terjadi autokorelasi yang bersifat positive atau negatif mendukung terhindarnya autokorelasi pada model yang digunakan dalam penelitian ini.

\section{Hasil Uji Analisis Model Regresi}

Analisis regresi linear berganda digunakan untuk mengetahui pengaruh secara linear antara variabel bebas dengan variabel terikat (Priyatno, 2017: 151). Berdasarkan hasil dari penelitian yang diolah menggunakan SPSS 23 , hasil uji regresi linear berganda dilihat dari nilai $B$ Unstandardized coefficients, maka diperoleh hasil persamaan regresi berganda sebagai berikut:

\section{$P M R=\alpha+\beta_{1} U K+\beta_{2} L V+\beta_{3} P B L+\beta_{4} U K A+\beta_{5} K I+\epsilon_{i t}$}

Dari hasil persamaan tersebut dapat dilihat hasil sebagai berikut :

1. Konstanta (a) memiliki nilai negatif sebesar 0,261 menunjukkan bahwa apabila Ukuran Perusahaan, Leverage, Profitabilitas, Ukuran Komite Audit, dan Kepemilikan Institusional diasumsikan tetap atau sama dengan 0, maka Pegungkapan Manajemen Risiko adalah 0,261 . 
2. Nilai koefisien regresi variabel Ukuran Perusahaan terhadap pengungkapan manajemen risiko sebesaar 0,019 . Nilai ini menunjukkan bahwa setiap peningkatan ukuran perusahaan satu satuan diprediksi akan meningkatkan pengungkapan manajemen risiko sebesar 0,019 .

3. Variabel Leverage memiliki nilai koefisien regresi yang negatif yaitu sebesar 0,009 . Nilai koefisien yang negatif ini menunjukkan bahwa setiap Leverage menurun sebesar satu satuan, maka besarnya pengungkapan manajemen risiko meningkat sebesar 0,009 atau setiap penurunan pengungkapan manajemen risiko sebesar satu satuan berarti telah terjadi peningkatan Leverage sebesar 0,009.

4. Nilai koefisien regresi variabel Profitabilitas terhadap pengungkapan manajemen risiko sebesaar 0,005 . Nilai ini menunjukkan bahwa setiap peningkatan profitabilitas satu satuan diprediksi akan meningkatkan pengungkapan manajemen risiko sebesar 0,005.

5. Nilai koefisien regresi variabel Ukuran Komite Audit terhadap pengungkapan manajemen risiko sebesaar 0,029. Nilai ini menunjukkan bahwa setiap peningkatan ukuran komite audit satu satuan diprediksi akan meningkatkan pengungkapan manajemen risiko sebesar 0,029 .

6. Variabel Kepemilikan Institusional memiliki nilai koefisien regresi yang negatif yaitu sebesar 0,028 . Nilai koefisien yang negatif ini menunjukkan bahwa setiap kepemilikan institusional menurun sebesar satu satuan, maka besarnya pengungkapan manajemen risiko meningkat sebesar 0,028 atau setiap penurunan pengungkapan manajemen risiko sebesar satu satuan berarti telah terjadi peningkatan kepemilikan institusional sebesar 0,028 .

Hasil Uji Hipotesis

Hasil Pengujian penelitian di uraikan dalam tabel 1 dibawah ini :

Tabel 1. Hasil Pengujian Penelitian dan Hipotesis

\begin{tabular}{l|c|c|c|c}
\hline \multicolumn{1}{c|}{ Variable } & $\begin{array}{c}\text { Unstadardized } \\
\text { Coefficients }\end{array}$ & $\begin{array}{c}\text { Standardized } \\
\text { Cofficients }\end{array}$ & $\begin{array}{c}\text { T-Test } \\
\text { Probability (Sig. a } \\
\text { 0,05) }\end{array}$ \\
\hline (Constant) & $-0,261$ & & $-1,362$ & 0,175 \\
Ukuran Komite Audit & 0,029 & 0,141 & 1,692 & 0,093 \\
Kepem. Institusional & $-0,028$ & $-0,089$ & $-1,051$ & 0,295 \\
Ukuran Perusahaan & 0,019 & 0,258 & 2,916 & 0,004 \\
Leverage & $-0,009$ & 0,022 & $-0,252$ & 0,802 \\
Probabailitas & 0,005 & 0,007 & 0,080 & 0,939 \\
R square & & & & 0,196 \\
Adjusted R Square & & & & 0,190 \\
F-test & & & 2,728 \\
Probability & & & & 0,022 \\
\hline
\end{tabular}

a. Dependent Variabel : Manajemen Resiko

b. Predictors : (Constant), Ukuran Komite Audit, Kep. Institusional, Ukuran Perusahaan, Leverage dan Probabilitas

Sumber data Annual Report dengan Aplikasi SPSS V. 23, (2019)

\section{Hasil Uji T}

Berdasarkan output pada tabel 1 diatas, pengujian hipotesis dalam penelitian ini dapat dijabarkan sebagai berikut :Bahwa hasil untuk variabel Ukuran Komite Audit (X1) menunjukkan bahwa nilai Sig. $>0,05$ atau 0,093 > 0,05. Maka, jawaban hipotesis yaitu Ha1 ditolak dan Ho1 
diterima yang berarti menyatakan bahwa tidak terdapat pengaruh Ukuran Komite Audit terhadap Pengungkapan Manajemen Risiko. Untuk hasil untuk variabel Kepemilikan Institusional (X2) menunjukkan bahwa nilai Sig. > 0,05 atau 0,295 >0,05. Maka, jawaban hipotesis yaitu $\mathrm{Ha}_{2}$ ditolak dan $\mathrm{Ho}_{2}$ diterima yang berarti menyatakan bahwa tidak terdapat pengaruh Kepemilikan Institusional terhadap Pengungkapan Manajemen Risiko. Untuk hasil untuk variabel Ukuran Perusahaan (X3) menunjukkan bahwa nilai Sig. $<0,05$ atau 0,004 $<0,05$. Maka, jawaban hipotesis yaitu $\mathrm{Ha}_{3}$ diterima dan $\mathrm{Ho}_{3}$ ditolak yang berarti menyatakan bahwa terdapat pengaruh Ukuran Perusahaan terhadap Pengungkapan Manajemen Risiko. Untuk hasil untuk variabel Laverage (X4) menunjukkan bahwa nilai Sig. > 0,05 atau 0,802 >0,05. Maka, jawaban hipotesis yaitu $\mathrm{Ha}_{4}$ ditolak dan $\mathrm{Ho}_{4}$ diterima yang berarti menyatakan bahwa tidak terdapat pengaruh Laverage terhadap Pengungkapan Manajemen Risiko. Kemudian untuk hasil untuk variabel Profitabilitas (X5) menunjukkan bahwa nilai Sig. $>0,05$ atau 0,936 >0,05. Maka, jawaban hipotesis yaitu $\mathrm{Ha}_{5}$ ditolak dan $\mathrm{H}_{5}$ diterima yang berarti menyatakan bahwa tidak terdapat pengaruh Profitabilitas terhadap Pengungkapan Manajemen Risiko.

\section{Hasil Uji F}

Hasil uji ANOVA diperoleh koefisien signifikan menunjukkan nilai signifikan 0,022. Artinya bahwa Sig. $<0,05$ atau 0,022 <0,05 bermakna bahwa model regresi dapat digunakan atau model layak untuk memprediksi Pengungkapan Manajemen.

\section{Hasil Uji Koefesien Determinasi}

Hasil menujukan bahwa adjustted $R$ Square untuk variabel Ukuran Perusahaan, Leverage, Profitabilitas, Ukuran Komite Audit, dan Kepemilikan Institusional diperoleh sebesar 0,196 . Hal ini berarti bahwa $19,6 \%$ dapat dijelaskan oleh variabel independen dalam model tersebut, sedangkan sisanya sebesar $80,4 \%$ dijelaskan oleh variabel lain.

\section{Pengaruh Ukuran Komite Audit terhadap Manajemen Resiko}

Komite Audit sebagai Komite Penunjang Dewan Komisaris diperkirakan dapat mempengaruhi praktik pengungkapan risiko suatu perusahaan. Hal tersebut diprediksi dengan efektifnya keberadaan dan kinerja Komite Audit dapat membantu Dewan Komisaris dalam fungsi pengawasan, khususnya dalam memastikan bahwa laporan keuangan telah disajikan secara wajar sesuai dengan prinsip akuntansi yang berlaku umum (KNKG, 2006). Hasil analisis data menunjukkan bahwa nilai signifikan variabel ukuran komite audit sebesar 0,093 yang berada di atas taraf signifikan 0,05 sehingga Ha dalam penelitian ini ditolak dan Ho diterima yang berarti bahwa ukuran komite audit yang diukur dengan jumlah komite audit dalam suatu perusahaan tidak berpengaruh terhadap pengungkapan manajemen risiko.

Penelitian ini sejalan dengan penelitian yang dilakukan oleh Mubarok dan Rohman (2013), Utomo dan Chariri (2014) dan Kencana dan Lastanti (2018) yang menunjukkan bahwa ukuran komite audit tidak berpengaruh terhadap pengungkapan manajemen risiko. berbeda dengan hasil penelitian ini, penelitian yang dilakukan oleh Syaifurakhman dan Laksito (2016) justru menunjukkan hasil bahwa ukuran komite audit berpengaruh terhadap pengungkapan manajemen risiko. hal ini dimungkinkan karena peranan komite audit dalam manajemen risiko perusahaan belum jelas (Kencana dan Lastanti, 2018). Hal ini juga dimungkinkan karena Perusahaan membentuk dan menetukan proporsi anggota komite audit dilakukan bukan untuk memaksimalkan kinerja, namun hanya untuk mematuhi peraturan dari Otoritas Jasa Keuangan (OJK) yaitu peraturan No.55/POJK.04/2015 tentang pembentukan dan pedoman pelaksanaan kerja komite audit (Kencana dan Lastanti, 2018). Mubarok dan Rohman (2013) mengindikasikan 
bahwa jumlah anggota komite audit yang lebih besar tidak mampu berkonstribusi secara signifikan terhadap kualitas pelaporan keuangan dibandingkan jumlah anggota komite audit yang lebih kecil. Jumlah anggota komite audit rata - rata perusahaan sampel yang cenderung stabil dan konstan bertentangan dengan luas pengungkapan risiko perusahaan yang cenderung dinamis dan berfluktuasi (Utomo dan Chariri, 2014).

\section{Kepemilikan Institusional Berpengaruh Terhadap Manajemen Resiko}

Kepemilikan institusional mempunyai kemampuan untuk mengontrol pihak manajemen dengan proses monitoring secara efektif sehingga mengurangi tindakan manajemen dalam melakukan manipulasi informasi mengenai risiko yang akan diungkapkan. Hasil analisis data menunjukkan bahwa nilai signifikan variabel kepemilikan institusional sebesar 0,295 yang berada di atas taraf signifikan 0,05 sehingga Ha dalam penelitian ini ditolak dan Ho diterima yang berarti bahwa kepemilikan institusional dalam suatu perusahaan tidak berpengaruh terhadap pengungkapan manajemen risiko. Penelitian ini sejalan dengan penelitian yang dilakukan oleh Mubarok dan Rohman (2013) yang menunjukkan bahwa kepemilikan institusional tidak berpengaruh terhadap pengungkapan manajemen risiko. berbeda dengan hasil penelitian ini, penelitian yang dilakukan oleh Mangena dan Pike (2005) justru menunjukkan hasil bahwa kepemilikan institusional berpengaruh terhadap pengungkapan manajemen risiko. Mubarok dan Rohman (2013) menyatakan bahwa teori keagenan memperkirakan bahwa struktur kepemilikan mempengaruhi tingkat pengawasan dalam perusahaan yang berdampak pada tingkat pengungkapan sukarela tidak terbukti. Hal ini dikarenakan perusahaan dengan struktur kepemilikan tidak harus mengungkapkan secara lebih informasi risiko, pemegang saham dapat secara mudah memperoleh dan biasanya dapat mengakses informasi tersebut (Mubarok dan Rohman, 2013). Utomo dan Chariri (2014) pengungkapan risiko yang tidak dipengaruhi oleh kepemilikan institusional yang dimiliki perusahaan dikarenakan perusahaan dengan struktur kepemilikan yang menyebar umumnya juga memberikan kemudahan kepada stakeholder - nya dalam mengakses maupun memperoleh informasi tentang perusahaan, termasuk informasi terkait risiko yang dihadapinya.

\section{Ukuran Perusahaan Berpengaruh Terhadap Manajemen Resiko}

Hasil analisis data menunjukkan bahwa nilai signifikan variabel ukuran perusahaan sebesar 0,004 yang berada di bawah taraf signifikan 0,05 sehingga Ha dalam penelitian ini diterima yang berarti bahwa ukuran perusahaan yang diukur dengan total aset dalam suatu perusahaan berpengaruh signifikan terhadap pengungkapan manajemen risiko. Penelitian ini sejalan dengan penelitian yang dilakukan oleh Jannah (2016), Syafitri et al (2016), Yunifa dan Juliarto (2017), dan Sarwono et al (2018). Ukuran perusahaan dapat menentukan besar kecilnya suatu perusahaan. semakin besar ukuran suatu perusahaan maka semakin besar pula risiko yang harus dihadapinya.

Perusahaan dengan ukuran besar memiliki kegiatan usaha yang lebih kompleks yang mungkin akan menimbulkan dampak lebih besar bagi perusahaan. Oleh karena itu sudah seharusnya perusahaan dengan ukuran besar memiliki tuntutan untuk menerapkan manajemen risiko agar risiko dapat dikelola dengan baik dan mengungkapkan risiko - risiko dengan detail sebagai bentuk transparansi publik atas risiko - risiko yang dihadapi terkait dengan tanggung jawab perusahaan dalam menyediakan laporan untuk keperluan internal (agent), dimana informasi tersebut juga digunakan sebagai bahan untuk memenuhi kebutuhan informasi kepada pihak eksternal (principal), sehingga tidak perlu mengeluarkan biaya tambahan. Sesuai dengan teori 
keagenan, perusahaan besar akan mengungkapkan informasi risiko yang lebih banyak dengan tujuan selain untuk memuaskan para pengguna laporan keuangan juga untuk mengurangi biaya keagenan dan untuk mengurangi asimetri informasi antara manajemen perusahaan dan pemilik.

\section{Leverage Berpengaruh Terhadap Manajemen Resiko}

Tingginya nilai leverage suatu perusahaan maka semakin luas juga pengungkapan risiko yang dilakukan oleh perusahaan. Hal tersebut dikarenakan semakin tingginya tingkat utang suatu perusahaan biasanya akan semakin berisiko. Selain itu, kreditur juga memerlukan pertanggungjawaban perusahaan kepada kreditur. Hasil analisis data menunjukkan bahwa nilai signifikan variabel laverage sebesar 0,802 yang berada di atas taraf signifikan 0,05 sehingga $\mathrm{Ha}$ dalam penelitian ini ditolak dan Ho diterima yang berarti bahwa leverage yang diukur dengan debt to asset ratio dalam suatu perusahaan tidak berpengaruh terhadap pengungkapan manajemen risiko. Penelitian ini sejalan dengan penelitian yang dilakukan oleh Jannah (2016), Kencana dan Lastanti (2018), dan Amran et al (2009) yang menunjukkan bahwa leverage tidak berpengaruh terhadap pengungkapan manajemen risiko. berbeda dengan hasil penelitian ini, penelitian yang dilakukan oleh Yunifa dan Juliarto (2017) dan Sarwono et al (2018) justru menunjukkan hasil bahwa leverage berpengaruh terhadap pengungkapa manajemen risiko.

Teori keagenan yang diungkapkan oleh Amran et al (2009) yang menjelaskan bahwa perusahaan dengan tingkat ketergantungan terhadap kreditur yang tinggi memiliki insentif yang kuat kepada manajemen untuk mengungkapkan informasi lebih luas tidak terbukti. Tingginya nilai leverage tidak selalu diikuti dengan semakin luasnya pengungkapan manajemen risiko dan menurunnya nilai leverage tidak selalu diikuti dengan menurunnya luas pegungkapan manajemen risiko. hal ini juga menjelaskan jika pengungkapan manajemen risiko bukan dilihat dari leverage dalam pembiayaan melainkan dari faktor lain. Hasil yang tidak signifikan kemungkinan dapat terjadi karena kreditor dapat memperoleh informasi mengenai risiko yang dihadapi perusahaan dengan mudah melalui prosedur pemberian pinjaman. Dengan demikian, perusahaan tidak harus mengungkapkannya secara luas karena kreditor sudah diberi cukup informasi mengenai risiko yang dihadapi dan antisipasi yang dilakukan perusahaan.

\section{Profitabilitas Berpengaruh Terhadap Manajemen Resiko}

Profitabilitas dapat diartikan sebagai kemampuan perusahaan untuk menghasilkan laba. Tingginya profitabilitas suatu perusahaan dapat menimbulkan ketertarikan investor untuk membeli saham atau berinvestasi di suatu perusahaan. Semakin besar profitabilitas yang dihasilkan perusahaan, maka akan semakin luas pengungkapan risiko yang harus dilakukan karena menunjukkan kepada Principal mengenai kemampuan perusahaan dalam mengefisienkan penggunaan modal di dalam perusahaannya. Hasil analisis data menunjukkan bahwa nilai signifikan variabel profitabilitas sebesar 0,936 yang berada di atas taraf signifikan 0,05 sehingga $\mathrm{Ha}$ dalam penelitian ini ditolak dan Ho diterima yang berarti bahwa profitabilitas yang diukur dengan net profit margin dalam suatu perusahaan tidak berpengaruh terhadap pengungkapan manajemen risiko.

Penelitian ini sejalan dengan penelitian yang dilakukan oleh Sarwono et al (2018) yang menunjukkan bahwa profitabilitas tidak berpengaruh terhadap pengungkapan manajemen risiko. berbeda dengan hasil penelitian ini, penelitian yang dilakukan oleh Jannah (2016) dan Yunifa dan Juliarto (2017) justru menunjukkan hasil bahwa profitabilitas berpengaruh terhadap pengungkapa manajemen risiko. Hasil pengujian ini tidak sesuai dengan teori agency yang diajukan yaitu, semakin tinggi tingkat profitabilitas suatu perusahaan akan menimbulkan ketertarikan principal 
untuk membeli saham di perusahaan tersebut dan semakin kuat kontrol eksternal perusahaan tersebut. Perbedaan antara hasil pengujian dengan teori yang diajukan dikarenakan perusahaan yang memiliki tingkat profitabilitas yang rendah akan lebih beresiko karena kemampuan perusahaan untuk memenuhi kebutuhan operasionalnya menjadi sangat sulit (Sarwono et al, 2018).

\section{Kesimpulan dan Saran \\ Kesimpulan}

1. Ukuran Komite Audit tidak berpengaruh terhadap Pengungkapan Manajemen Risiko pada perusahaan yang termasuk dalam index kompas 100 yang terdaftar di BEI pada periode 2016 $-2018$.

2. Kepemilikan Institusional tidak berpengaruh terhadap Pengungkapan Manajemen Risiko pada perusahaan yang termasuk dalam index kompas 100 yang terdaftar di BEI pada periode 2016 $-2018$.

3. Ukuran Perusahaan berpengaruh signifikan terhadap Pengungkapan Manajemen Risiko pada perusahaan yang termasuk dalam index kompas 100 yang terdaftar di BEI pada periode 2016 $-2018$.

4. Laverage tidak berpengaruh terhadap Pengungkapan Manajemen Risiko pada perusahaan yang termasuk dalam index kompas 100 yang terdaftar di BEI pada periode 2016 - 2018.

5. Profitabilitas tidak berpengaruh terhadap Pengungkapan Manajemen Risiko pada perusahaan yang termasuk dalam index kompas 100 yang terdaftar di BEl pada periode 2016 - 2018.

\section{Saran}

Peneliti selanjutnya diharapkan dapat melakukan penelitian pada perusahaan yang terdaftar di BEl yang terdapat pada index lainnya dan tidak terbatas pada index kompas seratus saja sesuai dengan kondisi yang dihadapi pada saat itu, Jumlah tahun penelitian bisa di perpanjang untuk tahun kebelakang dan tahun kedepan (terbaru) sehingga lebih menggambarkan ringkat pengungkapan manajemen risiko yang ada di indonesia, Untuk peneliti selanjutnya yang ingin melakukan kajian ulang terhadap penelitian ini disarankan untuk menambahkan variabel lain dan Menambah sumber - sumber informasi pengungkapan lainnya. Sehingga lebih dapat menggambarkan kondisi perusahaan. seperti laporan - laporan lainnya yang dikeluarkan oleh perusahaan, koran, majalah, dan informasi lainnya.

\section{Keterbatasan}

Pengukuran pengungkapan dalam penilitan ini dihitung dari banyaknya jumlah butir yang diungkapkan dibandingkan jumlah butir pengungkapan seharusnya, jika perusahaan mengungkapkan diberi nilai 1 dan jika tidak diberi nol, tanpa memberi bobot pada masing masing butir, dengan demikian nilai setiap butir sama, Pemberian nilai yang dilakukan penelitian setelah selesai membaca laporan tahunan perusahaan sampel tersebut berdasarkan interprestasi subjektif peneliti, sehingga setiap orang belum tentu memiliki penilaian yang sama. Hal ini disebabkan setiap pembaca memperhatikan pengungkapan risiko yang diungkapkan persahaan bisa dalam sudut pandang yang berbeda, Dalam penelitian ini hanya menggunakan perusahaan yang terdapat pada index kompas 100 yang terdaftar di BEI pada periode 2016 2018 dan penelitian ini belum mengkaji variabel lain yang mempengaruhi Pengungkapan Manajemen Risiko pada perusahaan yang terdapat di index kompas 100 yang terdaftar di BEl. 


\section{DAFTAR PUSTAKA}

Anisa, W. G. 2012. Analisis Faktor Yang Mempengaruhi Pengungkapan Manajemen Risiko. Skripsi Fakultas Ekonomi dan Bisnis Universitas Diponogoro, 22.

Amran, A., Manaf Rosli Bin, et all 2009. Risk reporting: An exploratory study on risk management disclosure in Malaysian annual repots. Managerial Auditing Journal, 24(1), 39-57. https://doi.org/10.1108/02686900910919893.

Effendi, Muh. Arief. 2009. The Power Of Corporate Governance: Teori dan Implementasi. Jakarta: Salemba Empat.

Harahap, Sofyan Syafri. 2016. Analisis Kritis Atas Laporan Keuangan.Jakarta:Pt Rajagrafindo Persada.

Jannah, I.M.M. 2016. Pengaruh tingkat leverage, profitabilitas dan ukuran perusahaan terhadap pengungkapan manajemen risiko. Artikel IImiah STIE PERBANAS Surabaya.

Kencana, A., \& Lastanti sri hexana. 2018. Pengaruh Good Corporate Governance, Dan Karakteristik Perusahaan Terhadap Nilai Perusahaan. Jurnal Bisnis Dan Akuntansi, 20(1), 21-32. https://doi.org/10.34208/jba.v20i1.404

KNKG. (2011). Draf Penerapan Manajemen Risiko Berbasis Governance.

Manik, Tumpal. 2017. Praktik Konservatisme Akuntansi Melalui Mekanisme Corporate Governance Terhadap Kualitas Laba. JIAFI. Vol.1, No.1. Oktober 2017

Mangena, M., Dan Pike, R. (2005). "The Effect Of Audit Committe Shareholding, Financial Expertise And Size On Interim Financial Disclosures". Accounting And Business Research, Vol. 18, No. 69, Pp. 327-349.

Mubarok, M. A., \& Rohman, A. 2013. Pengaruh Karakteristik Perusahaan dan Mekanisme Corporate Governance terhadap Pengungkapan Risiko Dalam Laporan Keuangan Interim (Studi empiris pada perusahaan-perusahaan nonkeuangan yang terdaftar di Bursa Efek Indonesia). 2(2), 833-879.

Rustam, Bambang Rianto. 2017. Manajemen Risiko: Prinsip, Penerapan, Dan Penelitian. Jakarta: Salemba Empat.

Syaifurakhman, B., Laksito, H., Akuntansi, J., Ekonomika, F., \& Diponegoro, U. (2016). FaktorFaktor Yang Mempengaruhi Pengungkapan Risiko (Studi Empiris Pada Perusahaan Manufaktur Yang Terdaftar Di Bursa Efek Indonesia Tahun 2014). Diponegoro Journal of Accounting, 5(4), 1-12.

Sugiyono.(2014). Metode Penelitian Kuantitatif dan R \& D. Bandung: CV Alfabeta.

Sarwono, A. A., Hapsari, D. W., \& Nurbaiti, A. 2019. Pengaruh Profitabilitas, Leverage dan Ukuran Perusahaan terhadap Pengungkapan Manajemen Risiko. Journal of Chemical Information and Modeling, 53(9), 1689-1699. https://doi.org/10.1017/CB09781107415324.004

Utomo, Y., \& Chariri, A. 2014. Determinan Pengungkapan Risiko Pada Perusahaan Nonkeuangan Di Indonesia. 03, 687-700.

Yunifa, L., \& Juliarto, A. 2017. Analisis Pengaruh Karakteristik Perusahaan Terhadap Tingkat Pengungkapan Risiko Pada Perusahaan Manufaktur. 6(3), 563-574. 